\title{
Gracilaria phuquocensis sp. nov., a new flattened Gracilaria species (Gracilariales, Rhodophyta), previously recognized as G. mammillaris, from the southern coast of Vietnam
}

\author{
Hau Nhu Le, ${ }^{1}$ Narongrit Muangmai, ${ }^{2,3 *}$ Sunisa Kheauthong, ${ }^{4}$ Zhongmin Sun ${ }^{5}$ and Giuseppe C. Zuccarello ${ }^{6}$ \\ ${ }^{1}$ Department of Organic Material from Sea Resource, Nha Trang Institute of Technology Research and Application, Vietnam \\ Academy of Science and Technology, Nha Trang, Vietnam, ${ }^{2}$ Department of Fishery Biology, Faculty of Fisheries, Kasetsart \\ University, Bangkok, Thailand, ${ }^{3}$ Graduate School of Integrated Science for Life, Hiroshima University, Hiroshima, Japan, ${ }^{4}$ Data and \\ Research Section, Thai Island and Sea National History Museum, Chon Buri, Thailand, ${ }^{5}$ Institute of Oceanography, Chinese Academy \\ of Sciences, Qingdao, China and ${ }^{6}$ School of Biological Sciences, Victoria University of Wellington, Wellington, New Zealand
}

\section{SUMMARY}

Flattened Gracilaria species are widely distributed along the coasts of the South China Sea with more than 20 species recorded. Within the South China Sea, Gracilaria mammillaris has only been reported from Vietnam, but this species is likely restricted to the western Atlantic. This study aimed to reevaluate the taxonomic status of Vietnamese specimens of 'G. mammillaris' using combined morphological and molecular data. Our data clearly indicated that Vietnamese specimens were morphologically and genetically distinct from authentic G. mammillaris from the western Atlantic, and also other described flat Gracilaria species. We, therefore, propose that specimens from Vietnam originally identified as G. mammillaris be designated as a new species, Gracilaria phuquocensis sp. nov. Morphologically, G. phuquocensis can be distinguished from other flat Gracilaria species by its small thallus size, narrower blades, many medullary layers, abundant basal nutritive filaments within mature cystocarps, and tetrasporangial nemathecium. Our $r b c L$ sequence analyses showed that the new species was sister to Gracilaria rhodymenioides from Thailand, and these two species formed a clade with cylindrical Gracilaria species. Our study contributes to clarification of the taxonomic status of misidentified specimens attributed to the flattened Gracilaria species in the South China Sea.

Key words: agarophyte, nemathecia, Pacific, phylogeny, seaweed.

\section{INTRODUCTION}

The marine red algal genus Gracilaria Greville has a wide distribution in tropical and temperate regions of the world, and currently contains 178 taxonomically accepted species (Guiry \& Guiry 2019). Due to its economic importance, the taxonomy and systematics of Gracilaria have been extensively studied (Núñez-Resendiz et al. 2015; Lyra et al. 2015a; Ng et al. 2017; Gurgel et al. 2018). Recently, new species of Gracilaria have been discovered on the basis of combined morphological and molecular data (Muangmai et al. 2014; Lyra et al., 2015b; Ardito et al. 2017; Muangmai et al. 2017;
Dreckmann et al. 2018; Hardesty \& Freshwater 2018; Soares et al. 2018).

Along the coastal areas of the South China Sea, more than 40 species of Gracilaria have been reported to date, about 20 of which are flattened species (Phang et al. 2016; Muangmai et al. 2017). In Vietnam, approximately 18 species of Gracilaria have currently been recorded, including seven with flattened thalli: Gracilaria cuneifolia (Okamura) I.K. Lee \& Kurogi, Gracilaria mammillaris (Montagne) M. Howe, Gracilaria punctata (Okamura) Yamada, Gracilaria spinulosa (Okamura) Chang \& B.M. Xia, Gracilaria textorii (Suringar) De Toni, Gracilaria vieillardii P.C. Silva and Gracilaria yamamotoi Zhang \& B.M. Xia (Le \& Nguyen 2006, Nguyen et al. 2013).

Among flat species, G. mammillaris has only been reported in Southeast Asian waters from Vietnam (Phang et al. 2016). Gracilaria mammillaris was originally described from Martinique in the eastern Caribbean Sea, and the distribution of this species seems to be restricted to the western Atlantic from the Caribbean south to Brazil (Gurgel et al. 2004; Hardesty \& Freshwater 2018). Considering this, it is feasible that the Vietnamese record of ' $G$. mammillaris' is based on misidentified specimens. Previous studies have also indicated that flattened Gracilaria specimens from the tropical Western Atlantic were misidentified as G. mammillaris and based on morphological and molecular evidences new species were proposed (Gurgel et al. 2004; Hardesty \& Freshwater 2018). Studies on the taxonomy of Gracilaria in Vietnam have relied mostly on morphology (Ohno et al. 1999; Le \& Nguyen 2006) and this can lead to incorrect identification. The objective of this study is to reassess the taxonomic identity of Vietnamese specimens identified as 'G. mammillaris' using morphological and $r b c L$ gene sequence analyses.
*To whom correspondence should be addressed.

Email: ffisnrm@ku.ac.th

Communicating editor: Wendy Nelson

Received 15 March 2019; accepted 30 May 2019. 


\section{MATERIAL AND METHODS}

\section{Sampling}

Specimens initially identified as G. mammillaris were collected from Phu Quoc Island, Kien Giang province, southern Vietnam $\left(105^{\circ} 42^{\prime} 58.86^{\prime \prime} \mathrm{E}, 19^{\circ} 6^{\prime} 10.75^{\prime \prime} \mathrm{N}\right.$ ) (Fig. S1 in the Supporting Information). Algal samples were either preserved as dry materials on herbarium sheets or fixed in $4 \%$ formalin/seawater. Type and voucher specimens were deposited in the Kasetsart University Museum of Fisheries (KUMF), Faculty of Fisheries, Kasetsart University, Bangkok, Thailand.

\section{Morphological investigation}

Transverse sections were made by hand using a razor blade, stained with $1 \%$ aniline blue, acidified with $1 \mathrm{~N} \mathrm{HCl}$, and mounted in $40 \%$ Karo syrup on microscope slide. Digital images were photographed using Olympus DP20 (Olympus, Tokyo, Japan) microscope digital camera and edited using Photoshop Elements 6 (Adobe, San Jose, CA, USA).

\section{Molecular analysis}

Apical portion of each voucher specimens was placed in silica gel until DNA extraction. Additional samples of G. yamamotoi from Quynh Tien, Nghe An province, northern Vietnam, and flat Gracilaria from Hainan Island, China were also genetically analyzed in this study. Total DNA was extracted using a $5 \%$ Chelex resin solution following Zuccarello et al. (1999). DNA amplification was carried out using the polymerase chain reaction (PCR) for the chloroplast $r b c L$ gene. PCR and sequencing of $r b c L$ gene were performed with two combinations of primers: rbcL-for and R753, plus F577 and $r b c \mathrm{~L}-\mathrm{rev}$ (Freshwater \& Rueness 1994; Nam et al. 2000). PCR procedures followed Zuccarello et al. (2002), products were confirmed by gel electrophoresis in $1 \%$ agarose gels. The PCR products were purified using ExoSAP-IT (USB, Ohio, USA) according to the manufacturer's instructions and subsequently sent for commercial Sanger sequencing (Macrogen Inc., Seoul, Korea).

The five newly determined sequences were edited and assembled using Geneious 11.0 software package (Biomatters, http://www.geneious.com). Data matrix were also prepared using Geneious 11.0 software and further modified manually. Data set of $r b c L$ included an additional 69 published sequences of the Gracilariaceae retrieved from GenBank (Table S1 in the Supporting Information). The genus Gracilariopsis was selected as an outgroup following Gurgel et al. (2004). All new sequences generated in this study were submitted to GenBank (accession number MK935560MK935564).

Phylogenetic trees were reconstructed using maximum likelihood ( $\mathrm{ML}$ ) and Bayesian Inference (BI). An appropriate model of sequence evolution was selected using Kakusan 4 (Tanabe 2011) for each analysis. The $r b c L$ dataset was partitioned by codon position, and separate DNA substitution models were chosen for each position. For ML analysis, phylogenetic trees were reconstructed using raxmIGUI $v 1.5 \mathrm{~b} 3$ (Silvestro \& Michalak 2012) under the option ' $\mathrm{ML}+$ thorough bootstrap' with 10 runs of random additional sequence generating 10000 nonparametric bootstrap replicates. BI analysis was implemented through MrBayes v3.2 (Ronquist et al. 2012). BI tree was reconstructed with two runs and four Markov Chain Monte Carlo (MCMC) chains with 10 million generations, sampling every 100 generations. Two independent runs were checked for stabilization of overall likelihood via Tracer v1.5 (Rambaut \& Drummond 2009). The first 25\% of trees were discarded as burn-in, and the remaining trees were used to calculate the Bayesian posterior probability (PP) for each clade. $\mathrm{ML}$ and $\mathrm{BI}$ trees were visualized and edited using FigTree v1.4.2 (Rambaut 2012).

\section{RESULTS}

A dataset of 1112 bp of $r b c L$ from various Gracilaria specimens was used for phylogenetic analysis (Fig. 1). The phylogenetic tree clearly indicated that our samples from Vietnam were placed in the major clade of Gracilaria and were evolutionarily distant from the type of G. mammillaris from Martinique in the eastern Caribbean Sea. Two rbcL sequences of Vietnamese samples were distinct from other Gracilaria sequences by at least $1.4 \%$ (16 bp) and differed from the type of $G$. mammilaris by about $5 \%$. Both $\mathrm{ML}$ and $\mathrm{BI}$ analyses yielded an identical topology, and therefore only the $M L$ tree (- In L score of -10097.0070 ) was presented (Fig. 1). The Vietnamese species was sister to Gracilaria rhodymenioides A.J.K. Millar from Thailand, and these two species formed a clade with two terete species, Gracilaria salicornia (C. Agardh) E.Y. Dawson and Gracilaria arcuata Zanardini. In contrast, G. yamamotoi from Vietnam and two unknown flat Gracilaria from Hainan Island, China were phylogenetically clustered with other flat species from Western Pacific species (Fig. 1).

Our phylogenetic analysis clearly showed that 'G. mammillaris' from Vietnam did not group with the type specimen of $G$. mammillaris and was distinct from all other Gracilaria species. We proposed that it be described as a new species:

Gracilaria phuquocensis N.H. Le, N. Muangmai \& G.C. Zuccarello sp. nov. (Figs 2-3)

\section{Diagnosis}

Plants were perennial, solitary, and flattened, 3-7 cm long, 3-5 mm wide and $250 \mu \mathrm{m}$ thick. Plants were dichotomously branched. Blades were composed of one to two pigmented cortical cells and five to eight unpigmented medullary cells. Tetrasporangia mostly occurred in nemathecia. Cystocarps were subglobose with variable levels of rostrate tips and constricted bases. Pericarps consisted of 17-25 cell layers. Nutritive filaments were abundant at the basal part of cystocarps.

\section{Type locality}

Kien Giang, Phu Quoc Island, Vietnam (10542'58.86"E, $\left.19^{\circ} 6^{\prime} 10.75^{\prime \prime} \mathrm{N}\right)$. 


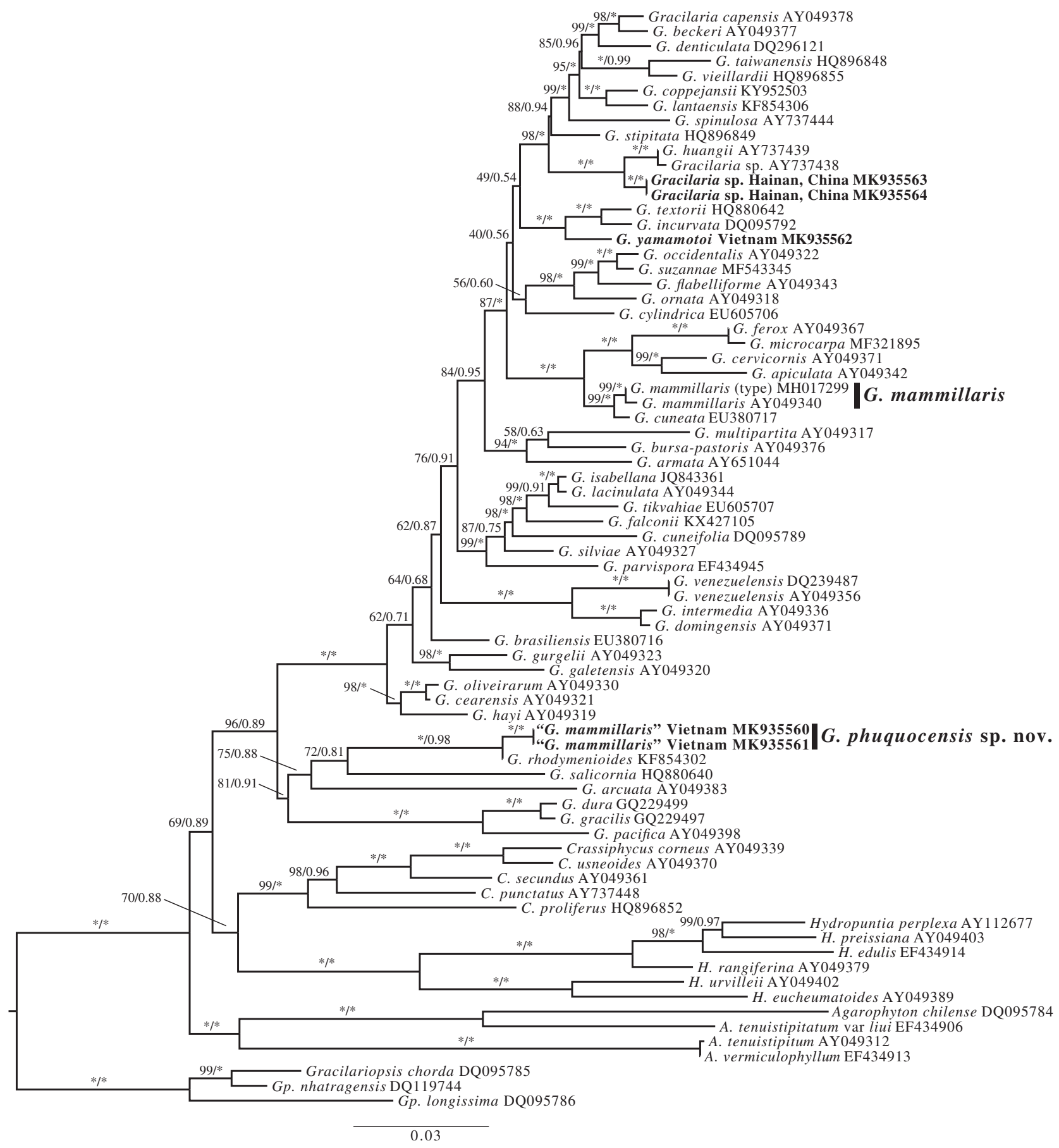

Fig. 1. Maximum-likelihood tree of partial $r b c L$ sequences. Support values at each node are bootstrap values from $M L$ (left) and Bayesian posterior probability (right). Asterisk (*) indicates full support $(100 \%, 1.0)$ in both analyses. Taxa in bold correspond to new sequences in this study.

\section{Type}

KUMF-NM1811001 (tetrasporophyte, Fig. 2a) deposited at KUMS, 5 October 2010, coll. Hau Nhu Le. Genbank accession number for rbcL: MK935560.

\section{Isotypes}

Hau 200122 (female gametophyte, Fig. 2b) (Genbank accession number for rbcL: MK935561), Hau 200105 (tetrasporophyte, Fig. 2c) and KUMF-NM1811002 (vegetative, Fig. 2d), deposited at KUMS, 5 October 2010, coll. Hau Nhu Le.

\section{Etymology}

The species epithet referred to the locality of Phu Quoc Island, where this species was found. 
a
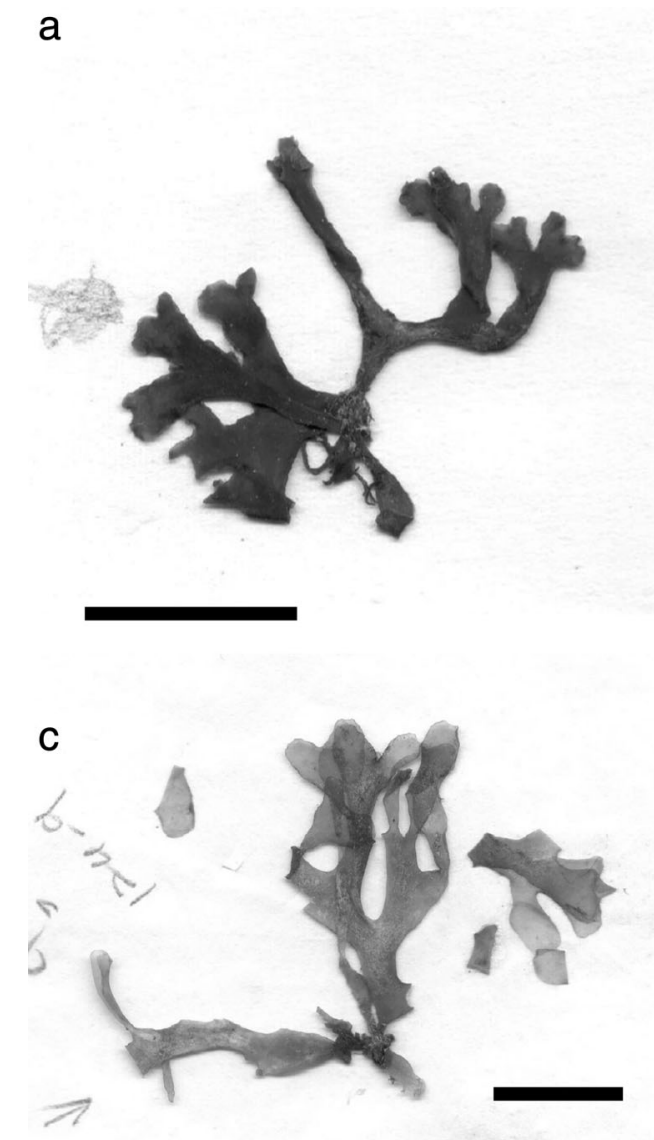

b 
a
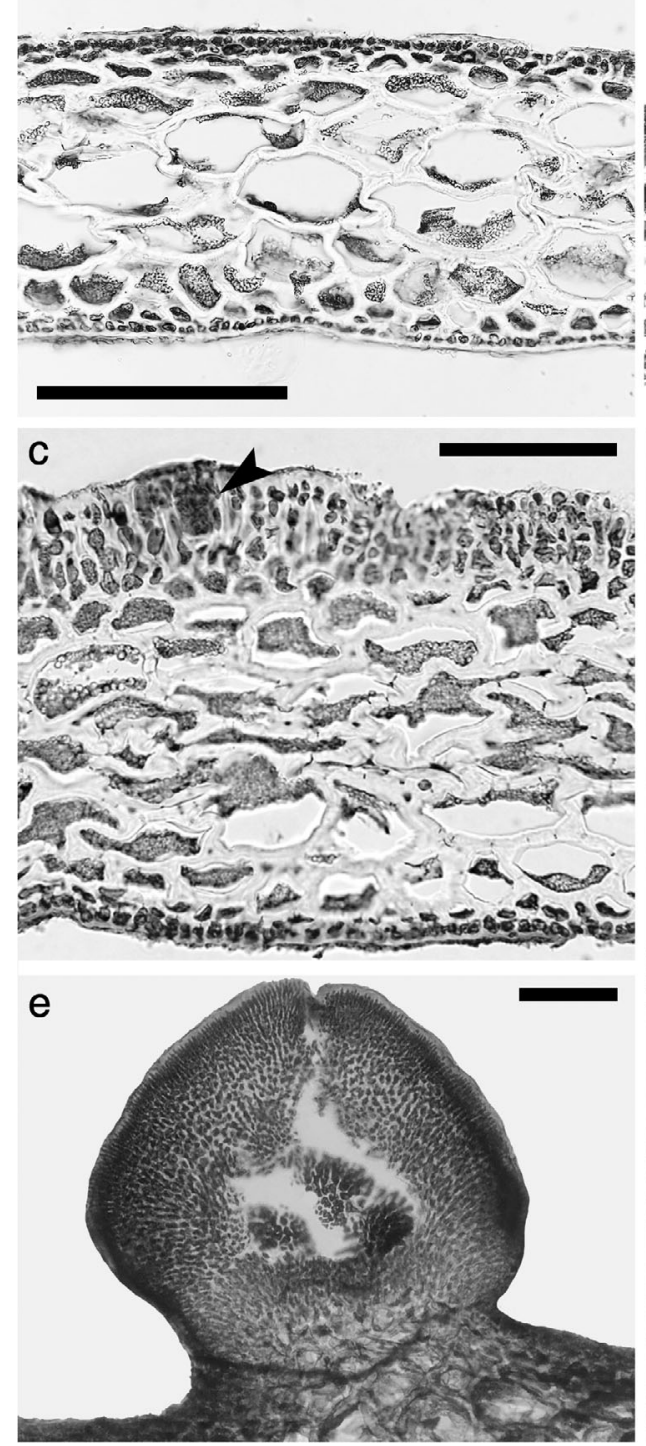

b
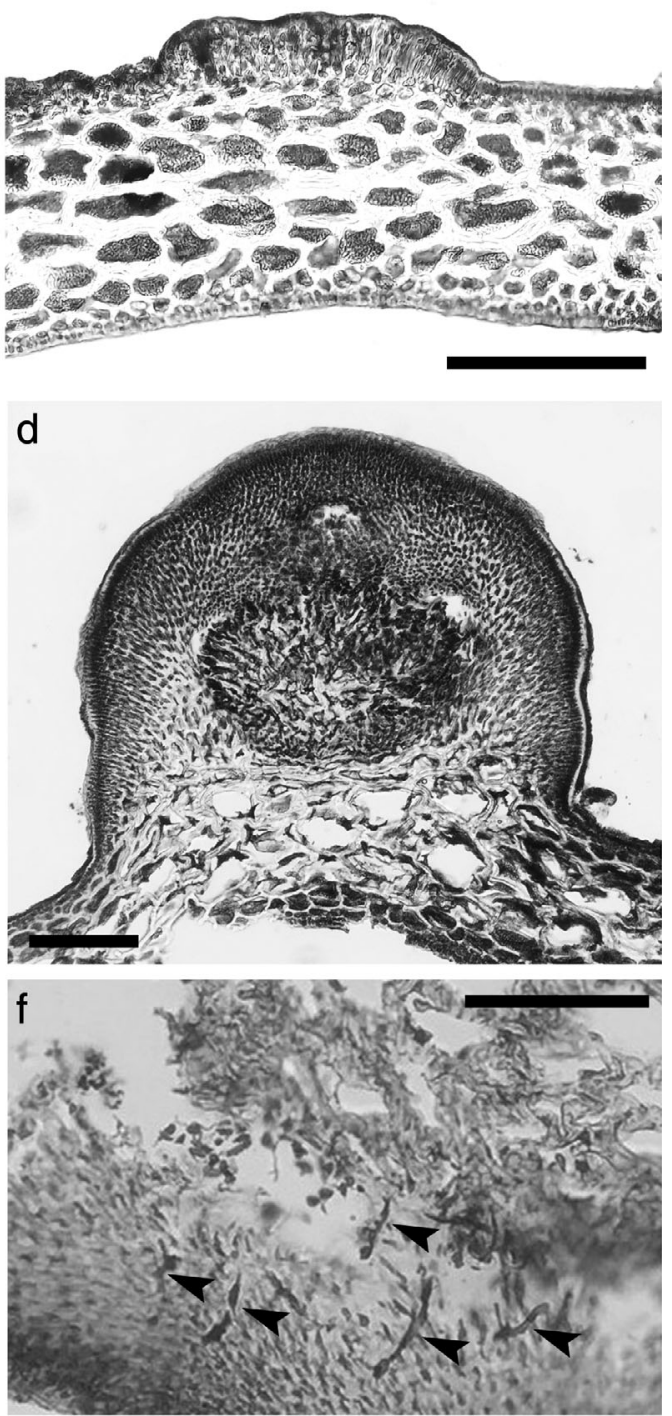

Fig. 3. Morphological characteristics of Gracilaria phuquocensis sp. nov. (a) Section of sterile plant, showing medullary cells and cell size transition, scale bar $=350 \mu \mathrm{m}$. (b) Tetrasporangial nemathecium in the surface of thallus, scale bar $=250 \mu \mathrm{m}$. (c) Close-up of tetrasporangia (arrowhead) in well-developed nemathecia, scale bar $=100 \mu \mathrm{m}$. (d) Cross-section of non-rostrate mature cystocarp, with a slight constriction at base, showing large gonimoblast cells and thickened pericarp cell layers, scale bar $=200 \mu \mathrm{m}$. (e) Section of rostrate mature cystocarp, with a conspicuous constriction at base, scale bar $=200 \mu \mathrm{m}$. (f) Mature cystocarp with numerous basal nutritive filaments (arrowheads) connecting to pericarp cells, scale bar $=200 \mu \mathrm{m}$.

and this characteristic has not been reported for any flattened Gracilaria species in Southeast Asian waters. On the other hand, a tetrasporangial nemathecium is relatively common for some flat Gracilaria species in the northeastern Pacific, for example, G. skottsbergii W.R.Taylor and G. rubrimembra E.Y. Dawson (Dawson 1949).

Gracilaria phuquocensis has only been found at Phu Quoc Island, southern Vietnam. Gracilaria phuquocensis could also be mistaken two other flattened species, G. cuneifolia and G. yamamotoi, from Vietnam. Although these three species are similar in external appearance, they can be distinguished based on the thickness of the medulla, cystocarp structure and tetrasporangia arrangement (Table 1). Gracilaria phuquocensis consists of more medullary layers (five to eight cells) than those two species (two to three cells in G. cuneifolia and four to five cells in G. yamamotoi). Cystocarps of $G$. phuquocensis mostly have its nutritive filamentous cells in the basal parts of carposporophytes, while other two species have upper and lateral nutritive cells (Table 1 ). Gracilaria phuquocensis also has more pericarp layers (17-25 cells) than found in G. cuneifolia (12-15 cells). Furthermore G. phuquocensis produces tetrasporangial nemathecia on only one side of the blade, whereas the other two species bear tetrasporangia immersed in the cortex on both sides of the 
Table 1. Comparisons of morphological features of Gracilaria phuquocensis and other related flat Gracilaria species

\begin{tabular}{|c|c|c|c|c|c|}
\hline Characters & G. phuquocensis ${ }^{a}$ & G. mammillaris ${ }^{b, c}$ & G. cuneifolia ${ }^{d, e, f, g}$ & G. yamamotoi ${ }^{d, f, h}$ & G. rhodymenioides s $^{i, j, k}$ \\
\hline Thallus height $(\mathrm{cm})$ & $3-7$ & up to 40 & $4-12$ & $5-6$ & $2-5$ \\
\hline Blade width (mm) & $3-5$ & up to 150 & $3-10$ & $3-5$ & $2-7$ \\
\hline Branching pattern & dichotomous & $\begin{array}{l}\text { pseudodichotomous/ } \\
\text { irregular }\end{array}$ & $\begin{array}{l}\text { dichotomous/ } \\
\text { irregular }\end{array}$ & $\begin{array}{l}\text { dichotomous/ } \\
\text { trichotomous }\end{array}$ & $\begin{array}{l}\text { dichotomous/ } \\
\text { trichotomous }\end{array}$ \\
\hline Medullary cell layers & $5-8$ & $3-4$ & $2-4$ & $4-5$ & $3-4$ \\
\hline $\begin{array}{l}\text { Nutritive filaments } \\
\text { within cystocarp }\end{array}$ & $\begin{array}{l}\text { abundant in } \\
\text { basal parts }\end{array}$ & unknown & $\begin{array}{l}\text { scattered in } \\
\text { all parts }\end{array}$ & $\begin{array}{l}\text { absent/ abundant } \\
\text { in lateral and } \\
\text { basal part }\end{array}$ & $\begin{array}{c}\text { abundant in lateral } \\
\text { and basal parts }\end{array}$ \\
\hline Pericarp layers & $17-25$ & unknown & $12-15$ & $14-18$ & $20-25$ \\
\hline Spermatangia & unknown & textorii-type & textorii-type & textorii-type & textorii-type \\
\hline Tetrasporangia & $\begin{array}{l}\text { borne in } \\
\text { nemethecia }\end{array}$ & embedded in cortex & $\begin{array}{l}\text { embedded } \\
\text { in cortex }\end{array}$ & $\begin{array}{l}\text { embedded in } \\
\text { cortex }\end{array}$ & embedded in cortex \\
\hline Distribution & Vietnam & Western Atlantic & Western Pacific & Western Pacific & $\begin{array}{l}\text { Indian Ocean and } \\
\text { Western Pacific }\end{array}$ \\
\hline
\end{tabular}

${ }^{a}$ This study.

${ }^{b}$ Gurgel et al. 2004.

${ }^{c}$ Gurgel et al. 2008.

${ }^{d}$ Zhang \& Xia 1994.

${ }^{e}$ Kim et al. 2006.

${ }^{f}$ Le \& Nguyen 2006.

${ }^{g}$ Muangmai et al. 2012.

${ }^{h}$ Terada \& Ueno 2004.

i Millar 1997.

${ }^{j}$ Lewmanomont \& Chirapart 2004.

${ }^{k}$ Muangmai et al. 2014.

blade. Phylogenetic analyses of $r b c L$ sequences also revealed that these three species are not closely related to each other. Gracilaria phuquocensis forms a clade with G. rhodymenioides and two other cylindrical species. Gracilaria cuneifolia grouped with many flattened Gracilaria species from the western Atlantic, and G. yamamotoi grouped with two Asian flattened species, G. incurvata Okamura and G. textorii (Suringar) Hariot.

Apart from similarities to other Vietnamese species, G. phuquocensis resembles G. rhodymenioides from Thailand. Even though both species are very similar in size, shape and branching pattern (Table 1), these two species are distinguishable based on cellular characteristics and cystocarp and tetrasporangia configuration. Blades of $G$. phuquocensis are thicker, consisting of more medullary cells, than G. rhodymenioides (three to four cells). While G. phuquocensis produces numerous basal nutritive filaments within cystocarps, in G. rhodymenioides nutritive filaments are both lateral and basal. Gracilaria phuquocensis possesses tetrasporangia in nemathecial sori, while G. rhodymenioides produces tetrasporangia embedded in an unmodified cortex.

Our molecular data also demonstrated that two flat Gracilaria specimens collected from Hainan Island, southern China were genetically distinct from other described Gracilaria species, and sister to two flattened species from Taiwan, an undescribed Gracilaria species and Gracilaria huangii S.-M. Lin \& De Clerck. It is obvious that further morphological analyses are required to confirm the taxonomic status of flattened Chinese specimens. Our study reveals that morphological similarity cannot alone be used to determine regional species diversity, such as that of the flattened Gracilaria species in the South China Sea, and a combination molecular and morphological examination is essential for these diversity studies.

\section{ACKNOWLEDGMENTS}

We are greatly indebted to Maren Preuss and Jakaphan Bulan for helping with molecular works, and Sinchai Maneekat for assisting with the microscope operation. We also thank Wendy Nelson and two anonymous reviewers for their suggestions and comments. Field collections and laboratory work were supported by Nha Trang Institute of Technology Application and Research, Vietnam and Kasetsart University, Thailand. Special thank goes to the GCRF GlobalSeaweedSTAR program for providing travel fund to NM.

\section{REFERENCES}

Ardito, M. S., Núñez-Resendiz, M. L., Dreckman, K. M. and Sentíes, A. 2017. Gracilaria falconii sp. nov. (Gracilariales, Rhodophyta): a new species with flat axes from Venezuela. Phytotaxa 292: 271-8.

Dawson, E. Y. 1949. Studies of northeast Pacific Gracilariaceae. Allan Hancock Found. Publ. Occup. Pap 7: 1-105.

Dreckmann, K. M., Núñez-Resendiz, M. L. and Sentíes, A. 2018. Gracilaria microcarpa sp. nov. (Gracilariaceae, Rhodophyta) from the southwestern Gulf of Mexico. Bot. Mar. 61: 115-25.

Freshwater, D. W. and Rueness, J. 1994. Phylogenetic relationships of some European Gelidium (Gelidiales, Rhodophyta) species based on $r b c L$ nucleotide sequence analysis. Phycologia 33: 187-94.

Guiry, M. D. and Guiry, G. M. 2019. AlgaeBase. World-wide electronic publication, National University of Ireland, Galway [Cited on 31 January 2019]. Available from: http://www. algaebase.org

Gurgel, C. F. D., Fredericq, S. and Norris, J. N. 2004. Molecular systematics and taxonomy of flattened species of Gracilaria Greville (Gracilariaceae, Gracilariales, Rhodophyta) from the Western Atlantic. In Abbott, I. A. and McDermott, K. J. (Eds). Taxonomy of 
Economic Seaweeds: with Reference to the Pacific and Other Locations, Vol. IX. Hawaii Seagrant College Program, Honolulu, pp. 159-99.

Gurgel, C. F. D., Fredericq, S., Norris, J. N. and YoneshigueValentin, Y. 2008. Two new flat species of Gracilaria (Gracilariales, Rhodophyta) from Brazil: G. abyssalis sp. nov. and G. brasiliensis sp. nov. Phycologia 47: 249-64.

Gurgel, C. F. D., Norris, J. N., Schmidt, W. E., Le, H. N. and Fredericq, S. 2018. Systematics of the Gracilariales (Rhodophyta) including new subfamilies, tribes, subgenera, and two new genera, Agarophyton gen. nov. and Crassa gen. nov. Phytotaxa 374: 1-23.

Hardesty, D. M. and Freshwater, D. W. 2018. Studies of North Carolina marine algae XIV: increased diversity of flattened offshore Gracilaria (Gracilariales, Rhodophyta) species revealed by DNA sequences of contemporary specimens and the G. mammillaris holotype. Bot. Mar. 61: 407-13.

Kim, M. S., Yang, E. C. and Boo, S. M. 2006. Taxonomy and phylogeny of flattened species of Gracilaria (Gracilariaceae, Rhodophyta) from Korea based on morphology and protein coding plastid $r b c \mathrm{~L}$ and $p s b A$ sequences. Phycologia 45: 520-8.

Le, N. H. and Nguyen, H. D. 2006. Contribution to the study of Gracilaria and related genera (Gracilariales - Rhodophyta) from Vietnam. Coast. Mar. Sci. 30: 214-21.

Lewmanomont, K. and Chirapart, A. 2004. Additional records of Gracilaria from Thailand. In Abbott, I. A. and McDermott, K. J. (Eds). Taxonomy of Economic Seaweeds: with Reference to the Pacific and Other Locations, Vol. IX. Hawaii Seagrant College Program, Honolulu, pp. 201-10.

Lyra, G. D. M., Costa, E. D. S., De Jesus, P. B. et al. 2015a. Phylogeny of Gracilariaceae (Rhodophyta): evidence from plastid and mitochondrial nucleotide sequences. J. Phycol. 51: 356-66.

Lyra, G. d. M., Gurgel, C. F. D., Costa, E. d. S. et al. 2015b. A new tropical species of Gracilariaceae (Rhodophyta, Gracilariales): Gracilaria silviae sp. nov. Phytotaxa 222: 199-210.

Millar, A. J. K. 1997. Some flattened species of Gracilaria from Australia. In Abbott, I. A. (Ed.). Taxonomy of Economic Seaweeds: with Reference to Some Pacific Species, Vol. VI. California Sea Grant College, La Jolla, CA, pp. 111-23.

Muangmai, N., Yamagishi, Y., Terada, R. and Kawagushi, S. 2012. A morphological and molecular study on the Gracilariaceae (Gracilariales, Rhodophyta) around the Hakata Bay, Northern Kyushu, Japan. J. Fac. Agr. Kyushu Univ 57: 411-20.

Muangmai, N., Zuccarello, G. C., Noiraksa, T. and Lewmanomont, K. 2014. A new flat Gracilaria: Gracilaria lantaensis sp. nov. (Gracilariales, Rhodophyta) from the Andaman coast of Thailand. Phycologia 53: 137-45.

Muangmai, N., Lewmanomont, K., Prathep, A., Terada, R. and Zuccarello, G. C. 2017. Gracilaria coppejansii sp. nov. (Gracilariales, Rhodophyta), a new flattened species from the Andaman coast of southern Thailand. Bot. Mar. 60: 533-41.

Nam, K. W., Maggs, C. A., Mclvor, L. and Stanhope, M. J. 2000. Taxonomy and phylogeny of Osmundea (Rhodomelaceae, Rhodophyta) in Atlantic Europe. J. Phycol. 36: 759-72.

Ng, P. K., Lin, S. M., Lim, P. E. et al. 2017. Genetic and morphological analyses of Gracilaria firma and G. changii (Gracilariaceae, Rhodophyta), the commercially important agarophytes in western Pacific. PLoS One 12: e0182176.

Nguyen, T. V., Le, N. H., Lin, S. M., Steen, F. and De Clerck, O. 2013. Checklist of the marine macroalgae of Vietnam. Bot. Mar. 56: 207-27.
Núñez-Resendiz, M. L., Dreckmann, K. M., Sentíes, A., DíazLarrea, J. and Zuccarello, G. C. 2015. Genetically recognizable but not morphologically: the cryptic nature of Hydropuntia cornea and H. usneoides (Gracilariales, Rhodophyta) in the Yucatan Peninsula. Phycologia 54: 407-16.

Ohno, M., Terada, R. and Yamamoto, H. 1999. The species of Gracilaria from Vietnam. In Abbott, I. A. (Ed.). Taxonomy of Economic Seaweeds with Reference to Some Pacific Species, Vol. VII. California Sea Grant College Program, La Jolla, CA, pp. 99-111.

Phang, S. M., Yeong, H. Y., Ganzon Fortes, E. T. et al. 2016. Marine algae of the South China Sea bordered by Indonesia, Malaysia, Philippines, Singapore, Thailand and Vietnam. Raffles Bull. Zool. Supp/ 40: 13-59.

Rambaut, A. 2012. FigTree v1.4.2: tree figure drawing tool. [Cited on 5 January 2019]. Available from: http://tree.bio.ed.ac.uk/software/ figtree/

Rambaut, A. and A.J. Drummond. 2009. Tracer-MCMC trace analysis tool version v1.4. [Cited on 10 December 2018]. Available from: http://beast.bio.ed.ac.uk/Tracer

Ronquist, F., Teslenko, M., van der Mark, P. et al. 2012. MrBayes 3.2: efficient Bayesian phylogenetic inference and model choice across a large model space. Syst. Biol. 61: 539-42.

Silvestro, D. and Michalak, I. 2012. raxmIGUI: a graphical front-end for RAxML. Organ Divers. Evol. 12: 335-7.

Soares, L. P., Gurgel, C. F. D. and Fujii, M. T. 2018. Grailaria suzanneae sp. nov. (Gracilariales, Rhodophyta), a new flattened species from northeast Brazil based on morphological and molecular evidence. Phycologia 57: 345-53.

Tanabe, A. S. 2011. Kakusan4 and Aminosan: two programs for comparing nonpartitioned, proportional and separate model for combined molecular phylogenetic analyses of multilocus sequence data. Mol. Ecol. Resour. 11: 914-21.

Terada, R. and Ueno, J. 2004. New record of Gracilaria yamamotoi Zhang et Xia (Rhodophyta) from Japan. In Abbott, I. A. and McDermott, K. J. (Eds). Taxonomy of Economic Seaweeds: with Reference to the Pacific and Other Locations, Vol. IX. Hawaii Seagrant College Program, Honolulu, pp. 243-7.

Zhang, J. F. and Xia, B. M. 1994. Three foliose species of Gracilaria from China. In Abbott, I. A. (Ed.). Taxonomy of Economic Seaweed with Reference to some Pacific Species, Vol. IV. California Sea Grant College, La Jolla, CA, pp. 103-10.

Zuccarello, G. C., West, J. A., Kamiya, M. and King, R. J. 1999. A rapid method to score plastid haplotypes in red seaweeds and its use in determining parental inheritance of haplotype plastids in the red alga Bostrychia (Ceramiales). Hydrobiologia 401: 207-14.

Zuccarello, G. C., Sandercock, B. and West, J. A. 2002. Diversity within red algal species: variation in world-wide samples of Spyridia filamentosa (Ceramiaceae) and Murrayella periclados (Rhodomelaceae) using DNA markers and breeding studies. Eur. J. Phycol. 37: 403-17.

\section{SUPPORTING INFORMATION}

Additional Supporting Information may be found in the online version of this article at the publisher's web-site:

Fig. S1. Map showing the sampling site.

Table S1. List of taxa used in this study and their GenBank accession numbers. 